ISSN 1678-3921

Journal homepage: www.embrapa.br/pab

For manuscript submission and journal contents, access: www.scielo.br/pab

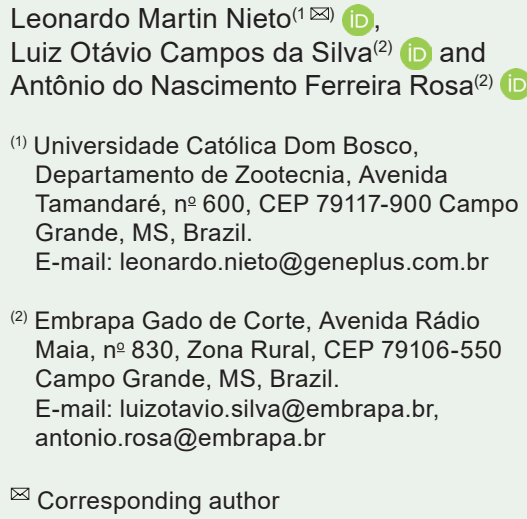

\section{Threshold models for the determination of genetic variability among reproductive traits in Nellore cattle}

\begin{abstract}
The objective of this work was to evaluate the potential of different threshold models to determine the genetic variability in Nellore cattle, with basis on the heritability estimates for the traits stayability (STA) and first calving probability at 36 months of age (CP36). Data came from the Nellore herds participating in the animal breeding program of the Embrapa-Geneplus partnership. Binomial and multi-threshold models were defined for the STA and CP36 traits. Heritability estimates were obtained following Bayesian procedures in the Multiple-trait Gibbs Sampler for Animal Models (MTGSAM) software, using a sire-maternal grandsire model. The heritability estimates, provided by the binary and alternative models, were, respectively, 0.08 and 0.12 for STA and 0.17 and 0.12 for CP36. The multi-threshold model can efficiently detect the genetic variability for stayability, but not for probability of calving for 36-month-old cows.
\end{abstract}

Index terms: Bayesian method, beef cattle, calving probability, stayability, threshold model.

\section{Modelos de limiar para a determinação da variabilidade genética em características reprodutivas em bovinos Nelore}

Resumo - O objetivo deste trabalho foi avaliar o potencial de diferentes modelos de limiar para a determinação da variabilidade genética em bovinos Nelore, com base nas estimativas de herdabilidade, quanto às características habilidade de permanência no rebanho (STA) e probabilidade de parto aos 36 meses de idade (CP36). Utilizaram-se dados provenientes dos rebanhos da raça Nelore participantes do Programa de Melhoramento Genético Animal da parceria Embrapa-Geneplus. Modelos binomiais e multilimiares foram definidos para as características STA e CP36. As estimativas de herdabilidade foram obtidas com uso de procedimentos bayesianos pelo programa Multipletrait Gibbs Sampler for Animal Models (MTGSAM), por meio do modelo touro-avô materno. As estimativas de herdabilidade, proporcionadas pelos modelos binário e alternativo, foram, respectivamente, 0,08 e 0,12 para STA e 0,17 e 0,12 para CP36. O modelo de múltiplos limiares é eficiente para a deteç̧ão de variabilidade genética quanto à característica habilidade de permanência no rebanho, mas não quanto à probabilidade de parto em vacas com 36 meses de idade.

Termos para indexação: método bayesiano, bovinos de corte, probabilidade de parto, probabilidade de permanência no rebanho, modelo multilimiar. 


\section{Introduction}

Bovine traits associated with the reproduction are extremely important for ensuring an efficient beef cattle selection. High-birth and survival rates result in more animals for sale, in commercial herds, or for selection in the case of purebred herds. Herds with more animals increase the selection intensity and, consequently, improve the desired genetic gains (Martín Nieto et al., 2013).

Except for age at first delivery, the interval between births and gestation period, which are continuous in nature, and other important reproductive traits, such as stayability and first calving probability, are categorical in nature. Categorical traits that can be distinguished into phenotypic classes are called threshold traits. The procedures for defining the phenotypic expression of these traits, and analyzing the underlying genetic data vary according to the number of classes per variable (Santos et al., 2012; Malhado et al., 2013), and according to the complexity of the interactions between the environment, animal genetics, physiology, and animal management. Not surprisingly, the application and definition of these traits as selection criteria remain poorly explored.

Traits such as first calving probability at 14 months (CP14) and STA have been evaluated in studies on Nellore breed cattle (ABCZ, 2018; AGRO-PECUÁRIA CFM, 2018; ANCP, 2018). These variables are usually described by binary classes, such as pregnancy (value 1) or not (value 0 ) at 14 months, and three or more calves by 76 months (value 1) or less than three calves by 76 months of age (value 0 ). However, the complex expression of these traits calls for alternative ways to evaluate them, to allow of a more faithful representation of the genetic variability existing in cattle herds, and to enable a more consistent progress through selection. In this sense, increasing the number of categories to more than two, as normally used, could represent an alternative way of assessing the categorical data (Malhado et al., 2013).

The objective of this work was to evaluate the potential of different threshold models to determine the genetic variability in Nellore cattle, with basis on the heritability estimates for the traits stayability (STA) and first calving probability at 36 months of age (CP36) traits.

\section{Materials and Methods}

The analyzed birth data, collected between 2006 and 2015, came from herds distributed in the Midwest region, whose breeding season was between October and January. The Nellore herds belonged to the Embrapa- Geneplus Genetic Breeding Program.

From these data set, two files containing information on STA and CP36 traits were prepared. In the first file, the STA trait was coded with a value of 1 for cows with at least three calves within 76 months of age, and a value of 0 for cows with fewer than three calves, thus defining a binomial threshold model. The age of 76 months was defined considering that cows would calve, on average, three times during this period. Data on cows that had not yet reached the age of six years were removed from the database.

In order to increase the possibility to identify a greater genetic variability for STA, an alternative coding was used in the second file, assigning values 0 , 1,2 , and 3 to cows with fewer than three, or with three, four, and five calves, respectively, within 76 months of age. This classification generated an alternative model of multiple thresholds.

For CP36, a first file was generated assigning a value of 1 to cows that naturally calved for the first time within 36 months of age, and assigning a value of 0 to those calved for the first time after 36 months of age, defining a binomial threshold model. As with STA, in the second file, an alternative coding was used for CP36 to facilitate the identification of genetic variability among individuals. Accordingly, codes 3, 2,1 , and 0 were assigned, respectively, to cows that calved for the first time before 32 months, at 33 or 34 months, at 35 or 36 months, and after 36 months of age, thus defining an alternative model of multiple thresholds.

The total numbers of records of sires and maternal grandparents in the files, generated for the analysis of the two traits are presented (Table 1).

Data consistency, descriptive analysis of the traits, and significance of the different nongenetic factors were assessed using the Statistical Analysis System software (SAS Institute Inc., Cary, NC, USA). From this initial assessment, the contemporary groups and the (covariates) variables, included in the models for genetic analysis, were defined. The groups of contemporaries were defined as follows: for STA farm and year of cow birth; and for CP36 - farm of

Pesq. agropec. bras., Brasília, v.55, e01181, 2020

DOI: 10.1590/S1678-3921.pab2020.v55.01181 
birth, year of birth, management groups at 120 days of age, weaning, and yearling of the cow. Groups whose mean was 0 , or 1 , for the traits under study, that is, without variability within the group of contemporaries, were eliminated.

For the genetic analyses, we applied Bayesian procedures in the Multiple-trait Gibbs Sampler for Animal Models (MTGSAM) software, developed by Van Tassell et al. (1998), under the sire-maternal grandsire single-trait model. The animal model could not be implemented due to convergence problems.

The concept of threshold (Falconer, 1965) presupposes that the responses are related to an underlying normal variable, usually called "liability" (९), and to a set of fixed thresholds that divide the real line into $\mathrm{m}$ intervals corresponding to the response categories.

It is assumed that the data are organized in a table of $\mathrm{s} \times \mathrm{m}$, where $\mathrm{s}$ rows represent combinations of explanatory variables, and $\mathrm{m}$ columns indicate response categories.

The $\mathrm{n}_{\mathrm{jk}}$ entries in this table are compounded by the number of observations in the $\mathrm{k}^{\text {th }}$ response category $(\mathrm{k}=1,2, \ldots, \mathrm{m})$ and in the $\mathrm{j}^{\text {th }}(\mathrm{j}=1,2, \ldots, \mathrm{s})$ row. The total number of nj rows is considered fixed.

The liability or predisposition (1) can be modeled as:

$$
\vartheta_{\mathrm{jq}}=\eta_{\mathrm{j}}+\varepsilon_{\mathrm{jq}} \text {, }
$$

in which:

$$
\mathrm{j}=1,2, \ldots, \mathrm{s} ; \mathrm{q}=1,2, \ldots \eta_{\mathrm{j}}+\varepsilon_{\mathrm{jq}} \sim \mathrm{N}(0,1),
$$

and: $\eta_{\mathrm{j}}$ is a location parameter for the $\mathrm{j}^{\mathrm{th}}$ combination of explanatory variables, and it is given a linear structure akin to that of the Taurus Model. Thus, the above model can be written as:

$$
\vartheta_{\mathrm{jq}}=\eta_{\mathrm{j}}+\varepsilon_{\mathrm{jq}}=\mathrm{W}_{\mathrm{jq}} \theta_{\mathrm{t}}+\varepsilon_{\mathrm{jq}},
$$

in which: $\vartheta_{\mathrm{jq}}$ is an underlying continuous variable of the $\mathrm{k}^{\text {th }}$ animal in the $\mathrm{j}^{\text {th }}$ combination; $\mathrm{W}_{\mathrm{jq}}$ is an incidence

Table 1. Total number of records of Nellore sires and maternal grandparents, in the databases used to analyze the stayability (STA) and first calving probability at 36 months of age (CP36) traits.

\begin{tabular}{lcc}
\hline Item / variable & STA & CP36 \\
\hline Number of records & 37,250 & 21,489 \\
Sires & 4,028 & 2,882 \\
Maternal grandparents & 1,017 & 684 \\
\hline
\end{tabular}

vector for the $\mathrm{jq}^{\text {th }}$ observation; and $\theta_{\mathrm{t}}$ defines the same fixed and random effects as the linear model.

CP36 was used to estimate the variance components and the genetic parameters for sexual precocity of females, whereas STA was used to determine the longevity. The model used included a group of contemporaries as a fixed effect, and the animal as a random effect for the analyzed traits.

The estimated heritability under the sire-maternal grandsire single-trait model was calculated as the fraction of phenotypic differences of genetic origin, in which: the additive genetic variance was $4 \sigma^{2}$ s (sire variance); the environmental variance was the residual variance $\left(\sigma_{\mathrm{e}}^{2}\right)$ fixed at 1 , in the case of the threshold model; and the phenotypic variance was $\sigma_{\mathrm{S}}^{2}+1 / 4 \sigma^{2} \mathrm{~S}$ plus the residual variance.

Gibbs chains with a 550,000 size were implemented in all analyses, with 50,000 disposal period and samples taken every 500 rounds. Thus, 1,000 samples were obtained to estimate each parameter, which allowed of the establishment of $95 \%$ confidence intervals of the subsequent distributions following data analysis by the Gibanal program (Van Kaam, 1997).

\section{Results and Discussion}

Position measurements (mean, mode, and median) and confidence intervals defining genetic parameters (sire variance $\left[\sigma_{S}^{2}\right]$ and heritability $\left[\mathrm{h}^{2}\right]$ ) for STA displayed similar values in each of the two classification models (Table 2).

Position measurements for $\sigma_{S}^{2}$ and $h^{2}$ were higher in the alternative model for STA (0.031, and 0.120) than in the binomial model (0.022, and 0.085), respectively. The proximity of the position measurement values,

Table 2. Position measurements (mean, mode, and median) and $95 \%$ confidence interval (CI) for genetic parameters calculated according to the binomial, or alternative coding model, for stayability in Nellore cattle.

\begin{tabular}{lccccc}
\hline Coding & $\begin{array}{c}\text { Genetic } \\
\text { parameter }\end{array}$ & Mean & Mode & Median & CI \\
\hline \multirow{2}{*}{ Binomial } & $\sigma^{2}{ }_{s}$ & 0.022 & 0.020 & 0.021 & $0.008-0.040$ \\
& $h^{2}$ & 0.085 & 0.084 & 0.085 & $0.033-0.151$ \\
\hline \multirow{2}{*}{ Alternative } & $\sigma^{2}{ }_{\mathrm{s}}$ & 0.031 & 0.031 & 0.031 & $0.020-0.045$ \\
& $\mathrm{~h}^{2}$ & 0.120 & 0.119 & 0.118 & $0.077-0.169$ \\
\hline
\end{tabular}

$\sigma_{S}^{2}$, sire variance; $h^{2}$, heritability.

Pesq. agropec. bras., Brasília, v.55, e 01181, 2020 DOI: 10.1590/S1678-3921.pab2020.v55.01181 
which is characteristic of a normal distribution, confirms that the Bayesian technique based on the iterative Gibbs sampling was performed correctly (Blasco, 2001). These results are an indication that STA was influenced by nonadditive and environmental genetic factors.

By analyzing STA from binary-coded data, Van Melis et al. (2010) and Santana Jr. et al. (2012) found 0.11 heritability value; however, values above $0.13,0.16$, and 0.19 were reported by Valente et al. (2017), Eler et al. (2014), and Schmidt et al. (2018), respectively. In general, different heritability magnitudes for STA can be attributed to the different models used, definitions of traits, and possible genetic differences in the assessed cattle populations. In all cases, the obtained heritability is low, suggesting that the long-term genetic gain for STA can be obtained using a binomial model to define the trait.

In the present study, the alternative coding criterion, with a higher number of thresholds, allowed of the identification of a greater genetic variability for STA $\left(\mathrm{h}^{2}=0.12\right)$ than that of the binary model $\left(\mathrm{h}^{2}=0.08\right)$. This finding is in agreement with the results obtained by Marcondes et al. (2005), who were the first authors to propose an alternative to the binary definition. According to these authors, an alternative way of classifying the variable can increase the ability to detect genetic variability in comparison to traditional criteria.

By the present study, we suggest that the inclusion of STA in genetic breeding programs can enable the selection of sires, whose daughters are more likely to remain productive for a longer period. However, it should be noted that the greater productive longevity of females, associated with a lower-replacement rate in herds, may increase the generational interval and, consequently, decrease the annual genetic gain.

As with STA, position measurements (mean, mode, and median) and confidence intervals defining genetic parameters (sire variance and heritability) for CP36 showed similar values in each of the models (Table 3 ).

Notably, in this case, the alternative model had proportionally lower-position measurements for $\sigma^{2}{ }_{S}$ and $h^{2}(0.032$, and 0.122$)$ than the binary model (0.045, and 0.170), respectively. Again, the proximity of position measurement values that is characteristic of a normal distribution confirmed that the Bayesian technique, based on iterative Gibbs sampling, was performed correctly (Blasco, 2001).

In the present study, the heritabilities obtained for CP36 in any of the models were lower than those reported by Malhado et al. (2013), for an alternative model of four thresholds $\left(\mathrm{h}^{2}=0.26\right)$, and a traditional binomial model $\left(\mathrm{h}^{2}=0.13\right)$ for the age at first delivery trait. Shiotsuki et al. (2009) evaluated pregnancies in heifers at 16 months of age using the binomial model, and reported 0.50 heritability. Similarly, Bonamy et al. (2019) obtained moderate to high values (0.29 to 0.56$)$ for early delivery of cows at 26,28 , and 30 months of age.

The lower values of heritability found in the present study may reflect the way databases were compiled for the analyses. Thus, considering only the information from cows that calved, the model could not correct a considerable source of phenotypic variation in the population. Moreover, the evaluated animals fed exclusively on pasture, which may have prevented the total expression of the trait and subsequent identification of genetic variability. Nutrition is an important factor in triggering puberty, as age alone does not stimulate the necessary physiological changes. Nutritional management of heifers influences not only weight, but also body score condition and the occurrence of puberty (Emerick et al., 2009; Basarab et al., 2012). Therefore, undernourished animals do not exhibit a significant variability in the expression of traits associated with the reproduction.

According to Martin et al. (1992), the effort to improve fertility through selection does not often have the expected results, which can be attributed to environmental interactions and methodological

Table 3. Position measurements (mean, mode, and median) and $95 \%$ confidence interval $(\mathrm{CI})$ for genetic parameters calculated according to the binomial, or alternative coding model, for first calving probability at 36 months of age (CP36) in Nellore cattle.

\begin{tabular}{lccccc}
\hline Coding & $\begin{array}{c}\text { Genetic } \\
\text { parameter }\end{array}$ & Mean & Mode & Median & CI \\
\hline \multirow{2}{*}{ Binomial } & $\sigma^{2} \mathrm{~s}$ & 0.045 & 0.044 & 0.044 & $0.034-0.057$ \\
& $\mathrm{~h}^{2}$ & 0.170 & 0.168 & 0.169 & $0.133-0.213$ \\
\hline \multirow{2}{*}{ Alternative } & $\sigma^{2} \mathrm{~s}$ & 0.032 & 0.032 & 0.032 & $0.026-0.039$ \\
& $\mathrm{~h}^{2}$ & 0.122 & 0.122 & 0.122 & $0.099-0.147$ \\
\hline
\end{tabular}

$\sigma^{2}$, sire variance; $h^{2}$, heritability. 
limitations related to the monitoring of traits associated with sexual precocity. In the case of first calving probability, there are only two possible outcomes calf or not -, and there are no intermediate degrees for the expression of this trait. Thus, the outcome on either side of the binary scale, calving or not, will also depend on environmental influences, such as nutrition and the length of the breeding season.

\section{Conclusion}

The multiple threshold model is suitable for detecting the genetic variability for stayability, but not for determining the first-calving probability of 36-month-old cows in Nellore cattle.

\section{References}

AGRO-PECUÁRIA CFM. Sumário de Touros Nelore CFM 2018. Available at: <http://www.agrocfm.com.br/wp-content/ uploads/2018/08/SumariodeTourosNeloreCFM2018.pdf >. Accessed on: Oct. 202018.

ABCZ. Associação Brasileira dos Criadores de Zebu. Sistema Integrado de Avaliação Genética. Available at: <https:// www.abczstat.com.br/comunicacoes/sumario/default. aspx?acesso=publico $>$. Accessed on: Oct. 202018.

ANCP. Associação Nacional de Criadores e Pesquisadores. Sumário de touros: Nelore, Guzerá, Brahman, Tabapuã: agosto 2018. Available at: <https://www.ancp.org.br/wp/wp-content/ uploads/2019/03/sumario-ancp-ago-2018.pdf>. Accessed on: Oct. 202018.

BASARAB, J.A.; FITZSIMMONS, C.; WHISNANT, C.S.; WETTEMANN, R.P. Interactions with other traits: reproduction and fertility. In: HILL, R.A. (Ed.). Feed efficiency in the beef industry. Ames: J. Wiley \& Sons, 2012. p.123-144. DOI: https://doi.org/10.1002/9781118392331.ch9.

BLASCO, A. The Bayesian controversy in animal breeding. Journal of Animal Science, v.79, p.2023-2046, 2001. DOI: https://doi.org/10.2527/2001.7982023x.

BONAMY, M.; KLUSKA, S.; PERIPOLLI, E.; LEMOS, M.V.A. de; AMORIM, S.T.; VACA, R.J.; LÔBO, R.B.; CASTRO, L.M. de; FARIA, C.U. de; FERRARI, F.B.; BALDI, F. Genetic association between different criteria to define sexual precocious heifers with growth, carcass, reproductive and feed efficiency indicator traits in Nellore cattle using genomic information. Journal of Animal Breeding and Genetics, v.136, p.15-22, 2019. DOI: https://doi.org/10.1111/jbg.12366.

ELER, J.P.; BIGNARDI, A.B.; FERRAZ, J.B.S.; SANTANA JR., M.L. Genetic relationships among traits related to reproduction and growth of Nelore females. Theriogenology, v.82, p.708-714, 2014. DOI: https://doi.org/10.1016/j.theriogenology.2014.06.001.
EMERICK, L.L.; DIAS, J.C.; GONÇALVES, P.E.M.; MARTINS, J.A.M.; LEITE, T.G.; ANDRADE, V.J.; VALE FILHO, V.R. Aspectos relevantes sobre a puberdade em fêmeas. Revista Brasileira de Reprodução Animal, v.33, p.11-19, 2009.

FALCONER, D.S. The inheritance of liability to certain diseases, estimated from the incidence among relatives. Annals of Human Genetics, v.29, p.51-76, 1965 . DOI: https://doi.org/10.1111/j.1469-1809.1965.tb00500.x.

MALHADO, C.H.M.; MALHADO, A.C.M.; MARTINS FILHO, R.; CARNEIRO, P.L.S.; PALA, A.; CARRILLO, A.J. Age at first calving of Nellore cattle in the semi-arid region of northeastern Brazil using linear, threshold, censored and penalty models. Livestock Science, v.154, p.28-33, 2013. DOI: https://doi. org/10.1016/j.livsci.2013.02.021.

MARCONDES, C.R.; PANETO, J.C. do C.; BEZERRA, L.A.F.; LOBO, R.B. Estudo de definição alternativa da probabilidade de permanência no rebanho para a raça Nelore. Revista Brasileira de Zootecnia, v.34, p.1563-1567, 2005. DOI: https://doi.org/10.1590/ S1516-35982005000500016.

MARTIN, L.C.; BRINKS, J.S.; BOURDON, R.M.; CUNDIFF, L.V. Genetic effects on beef heifer puberty and subsequent reproduction. Journal of Animal Science, v.70, p.4006-4017, 1992. DOI: https://doi.org/10.2527/1992.70124006x.

MARTÍN NIETO, L.; ALENCAR, M.M. de; ROSA, A. do N. Critérios de seleção. In: ROSA, A. do N.; MARTINS, E.N.; MENEZES, G.R. de O.; SILVA, L.O.C. da. (Ed.). Melhoramento genético aplicado em gado de corte: Programa GeneplusEmbrapa. Brasília: Embrapa, 2013. p.109-122.

SANTANA JR., M.L.; ELER, J.P.; FERRAZ, J.B.S.; MATTOS, E.C. Genetic relationship between growth and reproductive traits in Nellore cattle. Animal, v.6, p.565-570, 2012. DOI: https://doi.org/10.1017/S1751731111001856.

SANTOS, N.P. da S.; SARMENTO, J.L.R.; CAMPELO, J.E.G.; REGO NETO, A. de A.; FIGUEIREDO FILHO, L.A.S.; COSTA, M. da S.; BIAGIOTTI, D.; GUIMARÃES, F.F. Aplicação do modelo de limiar utilizando a inferência bayesiana no melhoramento animal. Pubvet, v.26, art.1427, 2012. DOI: https://doi.org/10.22256/pubvet.v6n27.1427.

SHIOTSUKI, L.; SILVA, J.A.IIV; ALBUQUERQUE, L.G. de. Associação genética da prenhez aos 16 meses com o peso à desmama e o ganho de peso em animais da raça Nelore. Revista Brasileira de Zootecnia, v.38, p.1211-1217, 2009. DOI: https://doi.org/10.1590/S1516-35982009000700008.

SCHMIDT, P.I.; CAMPOS, G.S.; LÔBO, R.B.; SOUZA, F.R.P.; BRAUNER, C.C.; BOLIGON, A.A. Genetic analysis of age at first calving, accumulated productivity, stayability and mature weight of Nellore females. Theriogenology, v.108, p.81-87, 2018. DOI: https://doi.org/10.1016/j.theriogenology.2017.11.035.

VALENTE, T.S.; ALBITO, O.D.; SANT'ANNA, A.C.; CARVALHEIRO, R.; BALDI, F.; ALBUQUERQUE, L.G.; PARANHOS DA COSTA, M.J.R. Genetic parameter estimates for temperament, heifer rebreeding, and stayability in Nellore cattle. Livestock Science, v.206, p.45-50, 2017. DOI: https://doi.org/10.1016/j.livsci.2017.10.010. 
VAN KAAM, J.B.C.H.M. GIBANAL: Analyzing program for Markov Chain Monte Carlo sequences. Version 2.3. Wageningen: Wageningen Agricultural University, 1997.

VAN MELIS, M.H.; ELER, J.P.; ROSA, G.J.M.; FERRAZ, J.B.S.; FIGUEIREDO, L.G.G.; MATTOS, E.C.; OLIVEIRA, H.N. Additive genetic relationships between scrotal circumference, heifer pregnancy, and stayability in Nellore cattle. Journal of Animal Science, v.88, p.3809-3813, 2010. DOI: https://doi.org/10.2527/jas.2009-2127.

VAN TASSELL, C.P.; VAN VLECK, L.D.; GREGORY, K.E. Bayesian analysis of twinning and ovulation rates using a multiple-trait threshold model and Gibbs sampling. Journal of Animal Science, v.76, p.2048-2061, 1998. 